\title{
Uji Efektivitas Putih Telur Ayam Kampung (Gallus domesticus) Terhadap Penyembuhan Luka Bakar Derajat II
}

\author{
Sri Juleli ${ }^{1}$, Arni Amir², Joserizal Serudji ${ }^{3}$ \\ ${ }^{1}$ Fakultas Kedokteran Universitas Andalas, Padang \\ ${ }^{2}$ Bagian Biologi Fakultas Kedokteran Universitas Andalas, Padang \\ ${ }^{3}$ Bagian Obgyn FK UNAND/RSUP Dr. M. Djamil Padang
}

\section{A B S T R A C T}

\begin{abstract}
Latar Belakang. Luka bakar merupakan masalah kesehatan yang terjadi secara global. Luka bakar menyebabkan morbiditas dan mortalitas yang cukup signifikan. Pengembangan terapi untuk mengobati luka bakar telah dilakukan bertahun-tahun, salah satunya dengan putih telur. Objektif. Untuk mengetahui efektivitas putih telur terhadap penyembuhan luka bakar derajat II pada mencit.

Metode. Penelitian eksperimental dengan menggunakan desain studi Posttest Only Control Group. Subjek penelitian ini berupa mencit jantan (Mus musculus) sebanyak 36 ekor dibagi menjadi 2 kelompok, yaitu kelompok perlakuan dengan pemberian putih telur dan kelompok kontrol dengan pemberian $\mathrm{NaCl} 0,9 \%$. Pengambilan jaringan dilakukan setelah terminasi hewan coba pada hari ke-3, hari ke-7, dan hari ke-14 kemudian dilakuan pembuatan preparat histologis untuk menilai pembuluh darah dan fibroblast.

Hasil. Jumlah rerat pembuluh darah pada kelompok kontrol pengamatan hari ke-3, hari ke-7, dan hari ke-14 secara berturut-turut ialah 38, 50, 36, 83 dan 29, 83. Kelompok perlakuan pengamatan hari ke-3, hari ke-7, dan hari ke-14 secara berturut-turut $25,33,55,00$, dan 44,66 . Jumlah rerata fibroblast pada kelompok kontrol pengamatan hari ke-3, hari ke-7, dan hari ke-4 secara berturut-turut ialah 48, 50, 41, 16 dan 36,83 . Kelompok pengamatan hari ke-3, hari ke-7, dan hari ke-14 secara berturut-turut 20, 83, 58, 16, dan 59, 00.

Kesimpulan. Tidak terdapat perbedaan signifikan jumlah pembuluh darah antara kelompok kontrol dan kelompok perlakuan pada hari ke-3 dan hari ke-7, sedangkan hari ke-14 terdapat perbedaan signifikan. Tidak terdapat perbedaan signifikan jumlah fibroblast antara kelompok kontrol dan kelompok perlakuan pada hari ke-3, hari ke-7, dn hari ke-14.

Kata kunci: putih telur, pembuluh darah, fibroblast, penyembuhan luka bakar.
\end{abstract}

Background. Burns is serious global health problem. Burnt wound contributes to significant higher morbidity and mortality rate. Development of therapy to heal burn has been developed using the egg white.

Objective. To indentify the healing effect of egg white on second degree burnt wound in rat.

Method. Experimental reaserch using post-test only control group design. The subjects were 36 male Mus musculus rats devide into 2 group: experimental group was given egg white and control group was given $\mathrm{NaCl} 0,9 \%$. The tissue retrival was done after the termination of the animals on the $3^{\text {rd }}, 7^{\text {th }}$, and $14^{\text {th }}$ days. Histological preparations were made to evaluate the vascular and fibroblast.

Result. Number of vascular in the observation control group day 3, day 7, and day 14 in a row was 38, 50, 36, 83 dan 29, 83. The number of vascular in the observation treatment group day 3, day 7 , and day 14 in a row was $25,33,55,00$, dan 44, 66. The number of fibroblast in the observation control group day 3 , day 7 , and day 14 in a row was 48, 50, 41,16 , dan 36,83 . The treatment groups on the $3^{\text {rd }}$ day, the $7^{\text {th }}$ day, and the $14^{\text {th }}$ day in a row are 20, 83, 58, 16 dan 59, 00. Conclusion. There is no significant differences amount of vascular in between control group and treatmant group on $3^{\text {rd }}$ day and $7^{\text {th }}$ day, whereas on the $14^{\text {th }}$ day there is a significant differences. There is no significant differences amount of fibroblast in between control group and treatmant group on $3^{\text {rd }}$ day, $7^{\text {th }}$ day, and day $14^{\text {th }}$ day.

Keywords: egg white, vascular, fibroblast, burn healing.

\section{Apa yang sudah diketahui tentang topik ini?}

Putih telur mengandung protein termasuk asam amino essensial dan vitamin. Protein tersebut mampu melepaskan faktor pertumbuhan yang berperan penting dalam proses penyembuhan luka bakar.

\section{Apa yang ditambahkan pada studi ini?}

Mengetahui efekivitas putih telur ayam kampung terhadap penyembuhan luka bakar derajat II pada mencit melalui pengamatan pembentukan pembuluh darah dan fibroblast.

\section{CORRESPONDING AUTHOR}

Nama: Sri Juleli

Phone: +6282326969660

E-mail: srisakerebau@gmail.com

\section{ARTICLE INFORMATION}

Received: September $23^{\text {rd }}$, 2020

Revised: October $15^{\text {th }}, 2020$

Available online: October $31^{\text {st }}$, 2020 


\section{Pendahuluan}

Luka bakar merupakan masalah kesehatan masyarakat yang cukup serius. Luka bakar berat menyebabkan morbiditas yang signifikan secara klinis, dibandingkan dengan cedera oleh sebab lain. ${ }^{1}$ Laporan World Health Organization (WHO) tahun 2018 menyatakan bahwa lebih dari 180.000 orang meninggal setiap tahunnya akibat luka bakar. Di India lebih dari 1 juta orang mengalami luka bakar sedang hingga berat setiap tahunnya. Tahun 2016, lebih dari 486.000 luka bakar terjadi di Amerika Serikat, dan sekitar 40.000 diantaranya memerlukan rawat inap. ${ }^{2} \mathrm{Di}$ Indonesia belum ada angka pasti mengenai luka bakar. Namun berdasarkan Rikesdas 2013 mengungkapkan bahwa luka bakar berada pada peringkat ke- 6 dalam cedera yang tidak disengaja dengan total $0,7 \%$ dari seluruh cedera. ${ }^{3}$.

Luka bakar (Combustio) adalah cedera pada kulit atau suatu kerusakan integritas pada kulit yang disebabkan oleh kontak dengan cairan panas, api, bahan kimia, arus listrik, dan radiasi. ${ }^{4}$ Luka bakar biasanya dinyatakan dengan derajat yang ditentukan oleh kedalaman jaringan tubuh yang rusak oleh trauma panas, tingginya suhu, lamanya paparan panas mengenai tubuh, dan rambatan panas pada jaringan. Beratnya luka bergantung pada luas, dalam, dan letak luka. Umur dan keadaan kesehatan penderita sebelumnya merupakan faktor yang sangat mempengaruhi prognosis. ${ }^{5}$

Prinsip utama penanganan luka bakar yaitu mencegah infeksi dan memberi kesempatan sisasisa sel epitel untuk berproliferasi dan menutup permukaan luka. Penyembuhan luka memiki tiga fase, yaitu fase inflamasi, proliferasi, dan remodeling. ${ }^{1}$ Tindakan yang dilakukan pada luka bakar adalah dengan memberikan terapi topikal yang bertujuan untuk mendapatkan kesembuhan secepat mungkin. Pengobatan yang cukup dikenal dalam dunia kesehatan adalah sintetik maupun pengobatan alamiah. ${ }^{6}$ Ada beberapa jenis obat sintetik yang dianjurkan seperti golongan silver sulfadiazine, hydrogel, dan Moist Exposure Burn Ointment (MEBO). Namun penggunaan obat medis yang terus menerus dapat menimbulkan efek samping, seperti iritasi, reaksi alergi termasuk rasa terbakar, gatal, dan ruam. Argyria neutropenia, toksisitas. ${ }^{7}$ Kelemahan lain dari penggunaan obat sintetik yaitu penyembuhan luka yang lambat, epitelisasi yang tidak lengkap, adanya bekas luka hitam atau hiperpigmentasi kulit, serta resisten terhadap bakteri. ${ }^{8}$ Sehingga diperlukan alternatif lain untuk mengobati luka bakar dengan efek samping yang minimal salah satunya adalah putih telur ayam kampung. Putih telur murni (tanpa kuning telur) mengandung sekitar 3,6 g protein murni termasuk semua asam amino esensial dan vitamin yang diperlukan untuk tubuh. ${ }^{9}$ Putih telur memiliki sifat terapeutik, imunogenik, dan fungsional selain nilai gizi yang tinggi. ${ }^{10}$ Kehadiran lisozim, ovalbumin, globulin G2 dan G3, dan ovamakroglobulin, imunoglobulin Y, dan senyawa antimikroba lainnya dalam telur dapat menginduksi imunogenisitas dan sifat antimikroba. ${ }^{9}$ Tryptophan adalah senyawa vital dan asam amino esensial yang hadir dalam putih telur. Aplikasi topikal asam amino ini dapat meningkatkan penyembuhan luka bakar pada tikus dengan meningkatkan epitelisasi, proliferasi sel dan proses neovaskularisasi. ${ }^{11}$ Kandungan ovamakroglobulin pada putih telur dapat menginduksi proliferasi dan migrasi sel fibroblast. 12

Berdasarkan uraian di atas peneliti tertarik untuk melakukan penelitian pengobatan luka bakar menggunakan putih telur melalui pengamatan pembentukan pembuluh darah dan fibroblast.

\section{Metode}

Jenis penelitian ini adalah eksperimental dengan rancangan posttest only control group. Pada penelitian dilaksanakan di Laboratorium Farmakologi Fakultas Farmasi Universitas Andalas dan laboratorium Patologi Anatomi Fakultas Kedokteran Universitas Andalas. Penelitian ini akan dilakukan pada bulan Februari 2020 sampai April 2020.

Populasi pada penelitian ini adalah mencit jantan (Mus musculus). Sampel adalah bagian dari populasi yang memenuhi kriteria inklusi dan eksklusi. Kriteria inklusi, meliputi mencit (Mus Musculus), berat 20-35 gram, berusia sekitar 8-12 minggu, aktifitas dan tingkah laku normal, dan tidak ada cacat anatomi. Kriteria eksklusi adalah mencit yang sebelumnya pernah digunakan dalam penelitian lain, luka bakar yang terbentuk terlalu dalam, luka bakar yang terbentuk terlalu superficial, dan mencit mati.

Besar sampel ditentukan berdasarkan kriteria WHO yang menyatakan bahwa setiap kelompok 
terdiri dari minimal 5 ekor untuk setiap kelompok, dilakukan koreksi besar sampel untuk antisipasi drop out sehingga jumlah total mencit dalam penelitian ini sebanyak 36 ekor. Masingmasing dibagi menjadi tiga untuk pengamatan hari ke-3, hari ke-7, dan hari ke-14 pada setiap kelompok perlakuan. Teknik pengambilan sampel pada penelitian ini dengan simple random sampling. Variabel independen pemberian putih telur dan variabel dependen pembentukan pembuluh darah baru dan fibroblast.

Prosedur penelitian dilakukan hewan coba dan putih telur. Mencit dipelihara dalam kandang yang telah diberikan sekat, diberi makan dan minum secara ad libitum. Persiapan bahan telur dipisahkan dari putih telur dengan kuning telur. Sediaan putih telur dibuat dengan kosentrasi $40 \%$, putih telur di ambil menggunakan spuit sebanyak $8 \mathrm{ml}$ ditambahkan $\mathrm{NaCl}$ 0,9 sebanyak 12 ml kemudian dicampur hingga homogen dan disimpan dalam wadah yang tertutup. Punggung hewan coba dicukur seluas 3-5 cm, lalu didisinfektan dengan alkohol 70\%. Selanjutnya mencit dianestesi secara inhalasi kloroform luka bakar dibuat menggunakan pelat besi berukuran $1,5 \times 1,5 \mathrm{~cm}$ yang telah dipanaskan sebelumnya dalam air mendidih (suhu $100^{\circ} \mathrm{C}$ ) selama setengah jam, kemudian ditempel pada punggung mencit selama 10 detik hingga terbentuk luka bakar derajat dua. Terapi diberikan satu jam setelah pembuatan luka bakar. Mencit dipisahkan sesuai dengan kelompok perlakuan masing-masing satu ekor per kandang. Mencit terminasi pada hari ke3, hari ke-7, dan hari ke-14 untuk mengambil jaringan kulitnya. Kulit yang telah disayat, kemudian disimpan dalam wadah yang telah diisi dengan formalin dan diberikan kode untuk tiaptiap wadah. Kulit tersebut dibuat preparat histologi dengan pewarnaan HE dan kemudian dinilai pembentukan pembuluh darah serta fibroblast di bawah miksroskop dengan perbesaran 400x pengamatan dilakukan pada 5 lapang pandang kemudian dirata-ratakan. Pengamatan dilakukan oleh dokter ahli Patologi Anatomi Fakultas Kedokteran Universitas Andalas.

Data yang diperoleh dicatat, ditabulasi, dan dianalisis dengan uji statistik t-independent test menggunakan SPSS 15.0. Hasil dinyatakan bermakna jika didapatkan $p<0.5$. Uji normalitas menggunakan Shapiro Wilk dengan siginifikan
( $p>0,05)$ dan uji homogenitas menggunakan Levene's Test dimana $(\mathrm{p}>0,05)$. Apabila data tidak berdistribusi normal dan tidak homogen, maka dilakukan uji Mann whitney. Penelitian ini telah mendapat persetujuan dari Komisi Etik Fakultas Kedokteran Universitas Andalas dengan nomor persetujuan etik 272/KEP/FK/2020.

\section{Hasil}

Hasil perhitungan pembuluh darah dan fibroblast pada kelompok kontrol dan kelompok perlakuan dapat dilihat pada tabel 1 dan tabel 2 berikut.

\section{Jumlah Pembentukan Pembuluh Darah pada Kelompok Kontrol dan Kelompok Perlakuan}

Tabel 1. Jumlah Rata-rata Pembuluh Darah pada Kelompok Kontrol dan Kelompok Perlakuan

\begin{tabular}{|c|c|c|c|}
\hline \multirow[b]{2}{*}{ Hari } & \multicolumn{2}{|c|}{ Rata-rata jumlah pembuluh darah } & \multirow[b]{2}{*}{$\mathbf{p}$} \\
\hline & $\begin{array}{c}\text { Kontrol } \\
\text { Mean } \pm \text { SD }\end{array}$ & $\begin{array}{l}\text { Perlakuan } \\
\text { Mean } \pm \text { SD }\end{array}$ & \\
\hline Hari ke-3 & $38,50 \pm 28,69$ & $25,33 \pm 9,62$ & 0,747 \\
\hline Hari ke-7 & $36,83 \pm 8,84$ & $55,00 \pm 30,51$ & 0,172 \\
\hline Hari ke-14 & $29,83 \pm 5,30$ & $44,66 \pm 14,00$ & 0,45 \\
\hline
\end{tabular}

Pada tabel 1 pengamatan hari ke-3 jumlah rerata pembuluh darah pada kelompok kontrol lebih banyak dibandingkan kelompok perlakuan, pengamatan hari ke-7 menunjukkan jumlah rerata pembuluh darah pada kelompok perlakuan lebih banyak dibandingkan pada kelompok kontrol dan pada pengamatan hari ke-14 jumlah pembuluh darah pada kelompok perlakuan lebih banyak dibandingkan kelompok kontrol.

\section{Jumlah Pembentukan Fibroblas pada Kelompok Kontrol dan Kelompok Perlakuan}

Tabel 2. Jumlah Rata-rata Fibroblast pada Kelompok Kontol dan Kelompok Perlakuan

\begin{tabular}{|c|c|c|c|}
\hline \multirow[b]{2}{*}{ Hari } & \multicolumn{2}{|c|}{ Rata-rata jumlah fibroblast } & \multirow[b]{2}{*}{$\mathbf{p}$} \\
\hline & $\begin{array}{c}\text { Kontrol } \\
\text { Mean } \pm \text { SD }\end{array}$ & $\begin{array}{l}\text { Perlakuan } \\
\text { Mean } \pm \text { SD }\end{array}$ & \\
\hline Hari ke-3 & $48,50 \pm 60,60$ & $20,83 \pm 6,94$ & 0,228 \\
\hline Hari ke-7 & $41,16 \pm 18,31$ & $58,16 \pm 25,52$ & 0,377 \\
\hline Hari ke-14 & $36,83 \pm 24,22$ & $59,00 \pm 28,02$ & 0,150 \\
\hline
\end{tabular}

Pada tabel 2 pengamatan hari ke-3 jumlah rerata pembuluh darah pada kelompok kontrol lebih banyak dibandingkan kelompok perlakuan, pengamatan hari ke-7 menunjukkan jumlah rerata pembuluh darah pada kelompok perlakuan lebih 
banyak dibandingkan pada kelompok kontrol dan pada pengamatan hari ke-14 jumlah pembuluh darah pada kelompok perlakuan lebih banyak dibandingkan kelompok kontrol.

\section{Pembahasan}

\section{Pengaruh Pemberian Putih Telur Terhadap Peningkatan Pembuluh Darah}

Penyembuhan luka adalah proses biologis alami terdiri dari serangkaian proses yang melibatkan respon seluler dan biokimia, baik secara lokal maupun sistemik. Proses penyembuhan luka bakar dibagi menjadi 3 fase, yaitu fase inflamasi, proliferasi, dan remodelling yang ketiganya saling tumpang tindih. Fase inflamasi diawali dengan reaksi hemostatis dan inflamasi neurogenik kulit, fase ini berlangsung pada hari sejak terjadinya luka hingga hari keempat. Fase ini ditandai oleh adanya reaksi inflamasi dan infiltrasi sel radang. ${ }^{13}$ Fase proliferasi berlangsung pada hari ke-3 hingga hari ke-14 ditandai oleh fibroplasia, deposisi matriks, angiogenesis, dan reepitelisasi. Fase terakhir dimulai pada minggu kedua setelah cedera mencakup perbaikan jaringan dan penyempurnaan jaringan baru untuk mengembalikan integritas kulit. Tahap terakhir berlangsung berbulan-bulan. ${ }^{14,15}$

Penelitian ini ingin mengetahui efek pemberian putih telur ayam kampung terhadap peningkatan jumlah pembuluh darah dan fibroblast. Dalam penelitian ini terdapat 2 kelompok perlakuan, yaitu kontrol sebagai luka bakar dengan pemberian $\mathrm{NaCl}$ 0,9\% dan kelompok perlakuan menggunakan putih telur. $\mathrm{NaCl}$ yang digunakan sebagai kontrol berupa sediaan tambahan yang sama pada putih telur. Peran putih telur terhadap proses penyembuhan luka adalah pada fase inflamasi dan fase proliferasi. Dari hasil pengamatan histologi rerata jumlah pembentukan pembuluh darah pada semua periode pengamatan hari ke-3, hari ke-7, dan hari ke-14 baik pada kelompok perlakuan maupun pada kelompok kontrol menunjukan hasil yang berbeda-beda. Rerata persentase pembentukan pembuluh darah pada kelompok kontrol dengan $\mathrm{NaCl}$ 0,9\% menurun dari hari ke-3 hingga hari ke-7 sebesar 5\%, dan hari ke-7 hingga hari ke-14 terjadi penurunan sebesar 24\%. Hal ini menandakan bahwa $\mathrm{NaCl}$ 0,9\% yang digunakan sebagai pembersih luka merupakan cairan steril, non pirogenik yang tidak memiliki efek fisiologis, dan antimikroba selama proses penyembuhan luka. Sedangkan pada kelompok perlakuan dengan menggunakan putih telur, rerata pesentase pembentukan pembuluh darah meningkat dari hari ke-3 hingga hari ke-7 sekitar 54\%, namun mengalami penurunan pada hari ke-14 sekitar $23 \%$. Putih telur mengandung protein ovalbumin yang berperan sebagai asam amino untuk growth faktor. Faktor pertumbuhan seperti VEGF dan FGF dapat menstimulasi pembentukan pembuluh darah, sehingga aplikasi topikal putih telur terhadap luka bakar memiliki pengaruh terhadap penyembuhan luka walaupun secara statistik tidak menunjukan perbedaan yang bermakna. ${ }^{16}$

Pada penelitian ini didapatkan jumlah rerata pembuluh darah pada hari ke-3 (fase inflamasi) antara kelompok kontrol dan kelompok perlakuan tidak terdapat perbedaan yang bermakna. Fase inflamasi dimulai pada detik pertama setelah cedera dan berlangsung hingga 3-4 hari. Pada fase ini terjadi pelepaskan dan pengaktifan sitokin berupa Transforming Growth Factor beta (TGF- $\beta$ ), IL-6, IL-8, IL-1 termasuk faktor pertumbuhan, meliputi Epidermal Growth Factor (EGF), PlateletDerived Growth Factor (PDGF), Fibroblast Growth Facktor (FGF), dan Vascular Endothelial Growth Factor (VEGF) yang menstimulasi pembentukan pembuluh darah dan fibroblast. Sitokin merangsang proliferasi sel inflamasi berupa neutrofil, makrofag, monosit, sel endotel, dan fibroblas. ${ }^{17}$

Makrofag diketahui mempunyai peranan penting dalam penyembuhan luka. Makrofag dapat melepaskan beberapa faktor pertumbuhan, seperti PDGF, FGF, TGF- $\beta$, dan VEGF yang merangsang neovaskularisasi dan pembentukan fibroblast, sehingga makrofag dapat berperan sebagai mediator pembentukan pembuluh darah pada terapi topikal putih telur terhadap luka bakar.18,19 Penurunan jumlah makrofag menunjukkan penutupan luka yang tertunda. Peningkatan jumlah monosit dan makrofag pada luka dapat secara signifikan mempercepat penyembuhan luka. ${ }^{20}$ Kandungan ovomucin, ovotransferrin, dan lisosim yang terdapat dalam putih telur dapat menstimulasi migrasi makrofag ke area luka. ${ }^{21,21}$ Rendahnya jumlah pembuluh darah pada pengamatan hari ke-3 diduga berkaitan belum cukup optimalnya mediator penyembuhan luka untuk menjamin proses 
pembentukan pembuluh darah. Hal ini sejalan dengan penelitian yang dilakukan oleh Hutagalung (2018) yang juga meneliti tentang efektivitas gel ekstra putih telur ayam kampung terhadap penyembuhan luka tikus melalui pengamatan jumlah makrofag. Dalam penelitiannya didapatkan jumlah rerata makrofag pengamatan hari ke-3 pada kelompok intervensi putih telur lebih sedikit $(3,63 \pm 1,50)$ dibandingkan kelompok kontrol $(3,93 \pm 1,44) .{ }^{23}$ Pengamatan hari ke-3 merupakan fase inflamasi. Pada fase inflamasi sel proinflamasi bermigrasi ke area luka oleh sitokin yang dilepaskan dari kaskade koagulasi. Monosit sel proinflamasi mulai bermigrasi setelah 48 jam pasca cedera, monosit kemudian berdiferensiasi menjadi makrofag yang merupakan mediator penyembuhan luka. ${ }^{24}$ Sitokin yang disekresi dari makrofag dapat mempengaruhi ekspresi VEGF. VEGF menstimulasi degradasi matriks ekstraseluler di sekitar sel endotel: Sel endotel dari daerah sekitar luka kemudian berproliferasi dan bermigrasi untuk membentuk kapiler baru. Angiogenesis tampak pada hari ke-4 pasca cedera, sehingga secara fisiologis pembentukan pembuluh darah tampak secara bermakna pada fase proliferasi. ${ }^{25}$

Pada penelitian ini jumlah rerata pembuluh darah pada hari ke-7 antara kelompok kontrol dan kelompok perlakuan tidak terdapat perbedaan yang bermakna. Pembentukan pembuluh darah dipengaruhi oleh faktor pertumbuhan seperti Fibroblast Growth Factor $\beta$ (FGF) dan Vascular Endothelial Growth Facktor (VEGF). FGF- $\beta$ adalah faktor kemotaksis dan mitogenik yang memicu angiogenesis dan menstimulasi migrasi serta pembentukan sel endotel. VEGF merupakan komponen utama dalam proses angiogenesis pada luka. VEGF berperan penting mempercepat proliferasi sel endotel, serta mempercepat pembentukan kapiler-kapiler pembuluh darah baru. ${ }^{26}$ Penelitian yang dilakukan oleh Morishije pada tahun 2013 dalam penelitiannya mengungkapkan bahwa lysophospatidic acid yang terdapat pada putih telur yang tidak dibuahi dapat menginduksi perkembangan pembentukan pembuluh darah. ${ }^{27}$ Putih telur mengandung sejumlah protein yang dapat memicu faktor pertumbuhan. Protein albumin yang terkandung dalam putih telur memiliki sifat terapeutik dan imunogenik. ${ }^{16}$ Aplikasi topikal putih telur pada luka bakar menunjukan peningkatan rerata jumlah pembuluh darah pada hari ke-7.

Pada pengamatan hari ke-14 jumlah rerata pembuluh darah antara kelompok kontrol dan kelompok perlakuan terdapat perbedaan yang bermakna. Hasil penelitian ini sesuai dengan studi penelitian Sadiq (2018) yang mendapatkan bahwa kelompok intervensi tryptophan menunjukan proses reepitelisasi yang baik dibandingkan kelompok kontrol dan pada pengamatan angiogenesis tampak jumlah pembuluh darah lebih banyak pada intervensi tryptophan dibandingkan pada kelompok kontrol pada hari ke-14. Hal ini menandakan bahwa kandungan tryptophan yang terdapat pada putih telur dapat menginduksi serta mengatur proses neovaskularisasi selama proses penyembuhan luka bakar dibandingkan pada kelompok kontrol pada. ${ }^{28}$ Jumlah rerata pembuluh darah hari ke-14 sedikit menurun dibandingkan hari ke-7. Pengamatan hari ke-14 sesuai dengan fase proliferasi atau fibroplasia. Fibroblast teraktivasi oleh faktor pertumbuhan kemudian bermigrasi dan berproliferasi menghasilkan kolagen dan molekul matrik ekstraseluler. Selama tahap awal proliferasi kapiler baru menjangkau ke jaringan mikrovaskular melalui jaringan granulasi. Pada fase akhir proliferasi, kepadatan pembuluh darah berkurang. Sehingga penurunan jumlah pembuluh darah pada pengamatan hari ke-14 terjadi karena pada akhir fase proliferasi fibroblast mulai menghilang segera setelah matriks kolagen mengisi kavitas luka dan pembuluh darah berdegenerasi melalui proses apoptosis. ${ }^{15}$

\section{Pengaruh Pemberian Putih Telur Terhadap Peningkatan Fibroblast}

Hasil pengamatan histologi menunjukkan rerata persentase pembentukan fibroblast pada kelompok kontrol dengan penggunaan $\mathrm{NaCl}$ 0,9\% mengalami penurunan dari hari ke-3 hingga hari ke-7 sebesar 5\%, dan hari ke-7 hingga hari ke-14 terjadi penurunan sebesar $24 \%$. Hal ini menandakan bahwa $\mathrm{NaCl}$ yang digunakan sebagai pembersih luka merupakan cairan steril, non pirogenik yang tidak memiliki efek fisiologis, dan efek antimikroba selama proses penyembuhan luka. Sedangkan pada kelompok perlakuan dengan menggunakan putih telur jumlah pembentukan fibroblast menunjukan akselerasi dari hari ke-3 hingga hari ke-7 sekitar 64\%, dan 
dari hari ke-7 hingga hari ke-14 sekitar 23\% sebagai puncak pembentukan fibroblast.

Pengamatan hari ke 3 menunjukkan rerata jumlah fibroblas pada kelompok kontrol lebih banyak dibandingkan kelompok perlakuan namun tidak terdapat perbedaan yang bermakna. Fibroblast berperan penting dalam penyembuhan luka normal. Fibroblast memproduksi matriks ekstraseluler yang akan mengisi kavitas luka. Fibroblast digunakan sebagai indikator penyembuhan luka karena sel ini merupakan sel dominan dalam proses penyembuhan luka. ${ }^{29}$ Putih telur mengandung protein ovalbumin yang berperan sebagai asam amino untuk growth faktor. Faktor pertumbuhan dapat menstimulasi migrasi dan pembentukan fibroblast. 16

Fibroblast merupakan komponen penting dari jaringan granulasi. Pembentukan jaringan granulasi terjadi pada hari keempat pasca cedera. ${ }^{17}$ Fibroblast yang terdapat pada jaringan granulasi mulai bermigrasi, berproliferasi, dan memproduksi komponen matriks ekstraseluler, seperti fibrin, fribronektin, glikosaminoglikan, proteoglikan, dan protein matrik ektraseluler. ${ }^{30}$ Dalam penelitian ini didapatkan pemberian putih telur pada luka bakar tidak memberikan pengaruh signifikan terhadap peningkatan fibroblast pada hari ke-3, yaitu fase inflamasi. Hal ini berbeda dengan penelitian yang dilakukan oleh Ritaningsih pada tahun 2018 yang juga meneliti tentang efektivitas gel putih telur pada luka bakar, pada penelitian yang dilakukan ditemukan peningkatan jumlah fibroblast secara bermakna pada hari ke-3 pada kelompok yang diberikan gel putih telur. ${ }^{31}$ Fibroblast muncul secara bermakna pada hari ke3 namun mencapai puncak pada hari ke-7.32

Pada pengamatan hari ke-7 dan hari ke-14 menunjukan rerata jumlah fibroblast antara kelompok kontrol dan kelompok perlakuan tidak terdapat perbedaan yang bermakna. Pengamatan hari ke-7 dan hari ke-14 sesuai dengan fase proliferasi atau fibroplasia. Fase proliferasi ditandai oleh fibroplasia, termasuk: proliferasi dan diferensiasi fibroblast menjadi miofibroblas, deposisi matrik ekstraseluler dan kontraksi luka, reepitelisasi dan interaksi epitel-mesenkimal antar keratinosit dan fibroblast, serta pembentukan pembuluh darah baru. Pembentukan fibroblast terjadi karena respon adaptif terhadap faktor pertumbuhan yang menstimulasi proliferasi dan diferensiasi fibroblast menjadi miofibroblas. 33

Aplikasi topikal putih telur pada luka bakar dapat menstimulasi migrasi sel fibroblast ke area luka pada hari ke-7 dan hari ke-14. Kandung Ovamakroglobulin yang terdapat pada putih telur dapat menstimuli pembentukan fibroblast selama proses penyembuhan luka. Hal ini sesuai dengan teori penelitian Geng pada tahun 2016, mengungkapkan bahwa ovamakroglobulin yang terkandung dalam putih telur berperan penting dalam penyembuhan luka. Dalam penelitiannya dilaporkan bahwa ovamakroglobulin dapat menginduksi migrasi 3 T6 fibroblas embrionik tikus dan Human Skin Fibroblas (HSF). ${ }^{34}$ Penelitian lain yang dilakukan oleh Hendriati pada tahun 2018 yang juga meneliti efektivitas gel putih telur terhadap penyembuhan luka bakar tikus. Pada penelitian yang dilakukan ditemukan bahwa fibroblast meningkat pada hari ke-7 dengan pemberian gel putih telur. ${ }^{35}$ Penelitian ini berbeda dengan penelitian yang dilakukan oleh Ritaningsih pada tahun 2018 dalam penelitiannya didapatkan pemberian gel putih telur pada luka bakar dapat meningkatkan jumlah fibroblast secara signifikan pada hari ke-7.30 Perbedaan penelitian ini disebabkan oleh faktor lokal yang mempengaruhi penyembuhan luka yang tidak diekslusikan. Beberapa faktor lokal yang mempengaruhi penyembuhan luka salah satunya adalah infeksi. Ketika luka mengalami infeksi, tubuh akan lebih fokus untuk melawan infeksi daripada menyembuhkan luka itu sendiri, sehingga penyembuhan luka terhambat. ${ }^{36}$

Berdasarkan hasil penelitian dan pembahasan sebelumnya dapat diambil kesimpulan bahwa jumlah rerata pembuluh darah pada hari ke-3 dan hari ke-7 antara kelompok kontrol dan kelompok perlakuan tidak terdapat perbedaan yang bermakna. Sedangkan jumlah rerata pembuluh darah pada hari ke-14 antara kelompok kontrol dan kelompok perlakuan berbeda bermakna. Pada pengamatan pembentukan fibroblast didapatkan jumlah rerata fibroblast antara kelompok kontrol dan kelompok perlakuan baik pada hari ke-3, hari ke-7 dan hari ke-14 tidak terdapat perbedaan yang bermakna. 


\section{Simpulan}

Berdasarkan hasil penelitian, peneliti menyarankan agar dilakukan penelitian lebih lanjut mengenai mekanisme kerja zat bioaktif putih telur terhadap penyembuhan luka bakar. Perlu dilakukan penelitian lebih lanjut mengenai efektivitas putih telur pada sediaan salep dan krim sebagai vehikulum yang tepat pembawa zat aktif yang paling efektif agar sediaan dapat meresap dengan baik pada kulit luka bakar mencit.

\section{Ucapan Terima Kasih}

Terima kasih kepada para Staff Laboratorium Farmakologi Fakultas Farmasi Unand dan Staff Laboratorium Patologi Anatomi serta Dosen ahli Patologi Anatomi Fakultas Kedokteran Universitas Andalas yang telah membantu dalam penelitian.

\section{Daftar Pustaka}

1. Sjamsuhidajat R, De jong. Buku ajar ilmu bedah. Edisi ke-3. Jakarta: EGC; 2010

2. World Health Organization (2018). WHO fact sheet on burns. http://www.who.int/en/news-room/factsheets/detail/burns. - Di akses Oktober 2018

3. Kementerian Kesehatan Republik Indonesia. Riset kesehatan dasar 2013. Jakarta: Kemenkes RI; 2013.

4. Awan SA. Astuti N, Bukhari A, Mahendradatta M, Tawali AB. Manfaat suplementasi ekstrak ikan gabusterhadap kadar albumin, MBA pada luka bakar derajata II. JTS Kesehatan. 2014;4(4):385-95.

5. Purwandianto A, Samourna B. kedaruratan medik. Jakarta: FKUI; 203.

6. Triana E, Nurhidayat N. Pengaruh pemberian beras yang difermentasi oleh Monascus purpureus Jmba terhadap darah tikus putih (Rattus Sp.) hiperkolesterolemia. Biodiversitas. 2006; 7(4):317321..

7. Pusat Informasi Obat Nasional (2015). Antiinfeksi untuk kulit: antibakteri. Badan POM RI. http://pionas.pom.go.id/ioni/bab-13-kulit/1310antiinfeksi-untuk-kulit/13101-antibakteri - Diakses Juli 2019.

8. Saeidinia et al. Partial-thickness burn wounds healing by topical treatment: A randomized controlled comparison between silver sulfadiazine and caltiderm. J Med. 2017; 96 (9):61-68.

9. Kelly ER, Plat J, Heanen GR, Kijlstra A, Berendschot TT. The efeect of modified eggs and egg-yolk based beverage on serum lutein and zeaxanthin concentrations and macular pigment optical density: result from a randomized trial. PloS one. 2014.

10. Fernandez ML. Effect of egg on plasma lipoproteins in healthy populations. J Food Funct. 2010; 1:156-60.

11. Jahani S, Ashrafizadeh H, Babai K, Siahpoosh A, Cheraghian B. Effect of ointment-based egg white on healing of second- degree wound in burn patients: a triple- blind randomized clinical trial study. Avicenna J Phytomed.. 2019; 9(3): 260-270..

12. Geng F, Xi H, Ma M. Hen egg white ovamacroglobulin promotes fibroblast migration via mediating cell adhesion and cytoskeleton. J Sci Food Agric. 2016; 96(9):3188-94.

13. Roussell P, Braye F, Dayan G. Re-epithelization of adult skin wound: cellular mechanism and therapeutic strategies. Advences drug delivery reviewes. 2019; 146: 344-365.

14. Visha MG, Karunagaran M. A riview on wound healing. Int J Clinicophatological Correlation. 2019; 2(3):56-59.

15. Rodrigues M, Kosaric N, Bonhan CA, Gurtner GC. Wound healing : A cellular perspective. American Physiological Society. 2019;99(1) :665-706.

16. Fernandez ML. effect of egg on plasma lipproteins in healthy population. J Food Funct. 2010;1:156-160.

17. Qing Chin. The molecular biology in wound healing \& non-healing wound. Chin J Traumatol. 2017;20(4):189-193.

18. Green MM, Melissa P, Lei W. chemokines and their receptors are key players in the orchestra that regulated wound healing. Wound care. 2013; 2: 32747.

19. Yanez DA, Locher RK, Vidyarthi A, Colegio OR. The role of macrophages in skin homeostatis. Pflugers arch. 2017;469:455-463.

20. Wynn TA, Vanella KM. Macrophages in tissue repair regeneration and fibrosis. Immunity-Elsevier Inc. 2016;44(3):450-460.

21. Yoo W, Araki T, Saito J, Kurata Y, Tokita K, Kato K, Matsushita M. Isolastion and characterization of a novel chicken egg white protein with scavenger receptor cysteine-rich domains. J.Poult.,Sci. 2013; 50:159-163.

22. Abdou MA, Hipashiguchi s, Aboueleinin Am, Kim M, Hisham R, Ibrahim. Antimicrobial peptides derived from hen egg lysozyme with inhibitory effect againt bacillus species. Journal of food control. 2007; 18(2):173-178.

23. Hutagalung MHP, Tarigan S. Efektivitas gel putih telur ayam kampung terhadap penyembuhan luka pasca pencabutan gigi tikus wistar jantan melalui pengamatan jumlah sel makrofag. Jurnal Mutiara KesMas. 2018; 3(1):80-89.

24. Gonzales AC, Costa TF, Andrade ZA, Medrado ARAP. Wound healing-A literature review. An Bras Dermatol. 2016; 91(5): 614-20.

25. Fiscal, Sardjono CT, Sandra F. Angiogenesis: patofisiologi dan aplikasi klinis. JKM. 2009; 8(2): 174-187.

26. Hariani L. Pola proses penyembuhan luka sekitar melalui analisis ekspresi EGF, VEGF, TGF-beta, MMP1 dan pembuluh kapiler yang diinduksi adiposed derived mesenchymal stem cells pada luka primer. (skripsi). Ilmu Kedokteran Jenjang Doktor Universitas Airlangga; 2017.

27. Morishige J, Uto Y, Hori H, Satauchi K, yoshiomoto T, Tokumura A. Lysophosphatidic acid produced by hen egg white lysophospholipase D induces vascular development on extraembryonic membranes. Springer-Verlag. 2013; 48: 251-262.

28. Alia Sadiq MQH, Gulshan Ara T, Ambreen J. Effect of essentian amino acid "Tryptophan" in post burn skin wound healing. Int J Biosci. 2018; 12:147-53

29. Primadina N, Bosari A, Perdanakusuma DS. Proses penyembuhan luka ditinjau dari aspek mekanisme seluler dan molekuler. Qanum Medika. 2019; 3(1):31-43. 
30. Tracy LE, Minasian RA, Caterson EJ. Extracellular matrix and dermal fibroblast function in the healing wound. Adv wound care. 2016; 5(3): 119-136.

31. Ritaningsih PM. Efektivitas gel putih telur pada luka bakar tikus putih (rattus novergicus) melalui pengamatan waktu penyembuhan luka dan kepadatan deposit kolagen. (Skripsi). Fakultas farmasi widya mandala;2016.

32. Gabriel A, Rosenberg LZ, I de Ia Torre J. Wound Healing and growth factors. 2018. http://emedicine.medscape.com/article/1298196overview\#a1. Diakses 4 Febreuari 2019.

33. Dorantes LC, Ayala MC. Skin acute wound healing: a comprehensive review. Int J Inflamasy; 2019.

34. Geng F, Xi H, Ma M. Hen egg white ovamacroglobulin promotes fibroblast migration via mediating cell adhesion and cytoskeleton. J Sci Food Agric. 2016; 96(9):3188-94.

35. Hendriati L, Hamid IS, Widodo T, Wandasari C, Mirah Rista P. Efek gel putih telur terhadap penyembuhan luka bakar pada tikus putih (Rattus novergicus). J Ilmu Kefarmasian Indonesia. 2018; 16(2): 231-237.

36. Sjamsuhidajat R, De jong. Buku ajar ilmu bedah. Edisi ke-3. Jakarta: EGC; 2010. 